\title{
Cyathus morelensis, a rare bird's nest fungus in the Brazilian Amazon rainforest
}

\section{Cruz RHSF ${ }^{1^{*}}$, Lima RAA ${ }^{1}$, Braga-Neto $\mathbf{R}^{2}$ and Baseia IG $^{3}$}

\begin{abstract}
${ }^{1}$ Universidade Federal do Rio Grande do Norte, Programa de Pós Graduação em Sistemática e Evolução, Centro de Biociências, Campus Universitário, 59072-970, Natal, RN, Brazil (rhudsoncruz@ yahoo.com.br)

${ }^{2}$ Instituto Nacional de Pesquisa da Amazônia, Departamento de Ecologia, Coordenação de Pesquisas em Ecologia, Av. Efigênio Sales, 2239, BOX 2239, Coroado, 69011-970, Manaus, AM, Brazil (saci007@ gmail.com)

${ }^{3}$ Universidade Federal do Rio Grande do Norte, Departamento de Botânica, Ecologia e Zoologia, Campus Universitário, 59072-970, Natal, RN, Brazil (baseia@cb.ufrn.br)
\end{abstract}

Cruz RHSF, Lima RAA, Braga-Neto R, Baseia IG 2012 - Cyathus morelensis, a rare bird's nest fungus in the Brazilian Amazon rainforest. Mycosphere 3(5), 880-882, Doi 10.5943 /mycosphere/3/5/13

Cyathus morelensis, an uncommon species of bird's nest fungi, is described for the second time in the world from the Brazilian Amazon rainforest. A detailed description, taxonomical remarks, photographs of basidiomata and illustrations of basidiospores, peridiole and basidiomata are provided.

Key words - Basidiomycota - gasteromycetes - neotropics - taxonomy

\section{Article Information}

Received 26 September 2012

Accepted 1 October 2012

Published online 24 October 2012

*Corresponding author: Rhudson Cruz - e-mail - rhudsoncruz@yahoo.com.br

\section{Introduction}

Cyathus Haller: Pers. is a genus represented by small fungi of the family Nidulariaceae that exhibit cup or bell-shaped basidiomata (Brodie 1975), occurring in several Brazilian biomes (Baseia \& Milanez 2001, Cruz et al. 2012). However, studies with this peculiar group of gasteroid fungi are still scarce and the number of records is insignificant when compared to the as yet unknown diversity likely existing in the Amazon forest.

A project recently initiated to study gasteroid fungi in the Adolpho Ducke Reserve Forest has led to the discovery of interesting new species (Alfredo et al. 2012a, b). As part of a taxonomic review of gasteroid fungi in areas of the Brazilian Amazon, the aim of the present investigation is to widen taxonomic knowledge of species that occur in a number of Brazilian biomes.

\section{Methods}

Specimens were obtained during scientific expeditions in 2010 to the Adolpho Ducke Reserve Forest, in Manaus, Brazil. Macroscopic features were described from fresh and dried specimens. Microscopic data were obtained from sections of peridioles in $5 \% \mathrm{KOH}$ (Brodie 1975) on glass slides and observed under an Olympus BX41 light microscope (LM). Thirty randomly selected basidiospores were measured under the LM at 400x magnification. Colours were defined by Kornerup \& Wanscher (1978), and vouchers were deposited in the INPA Herbarium. Abbreviations used in spore descriptions follow Zhao et al. (2008): "Qm" is the mean of 

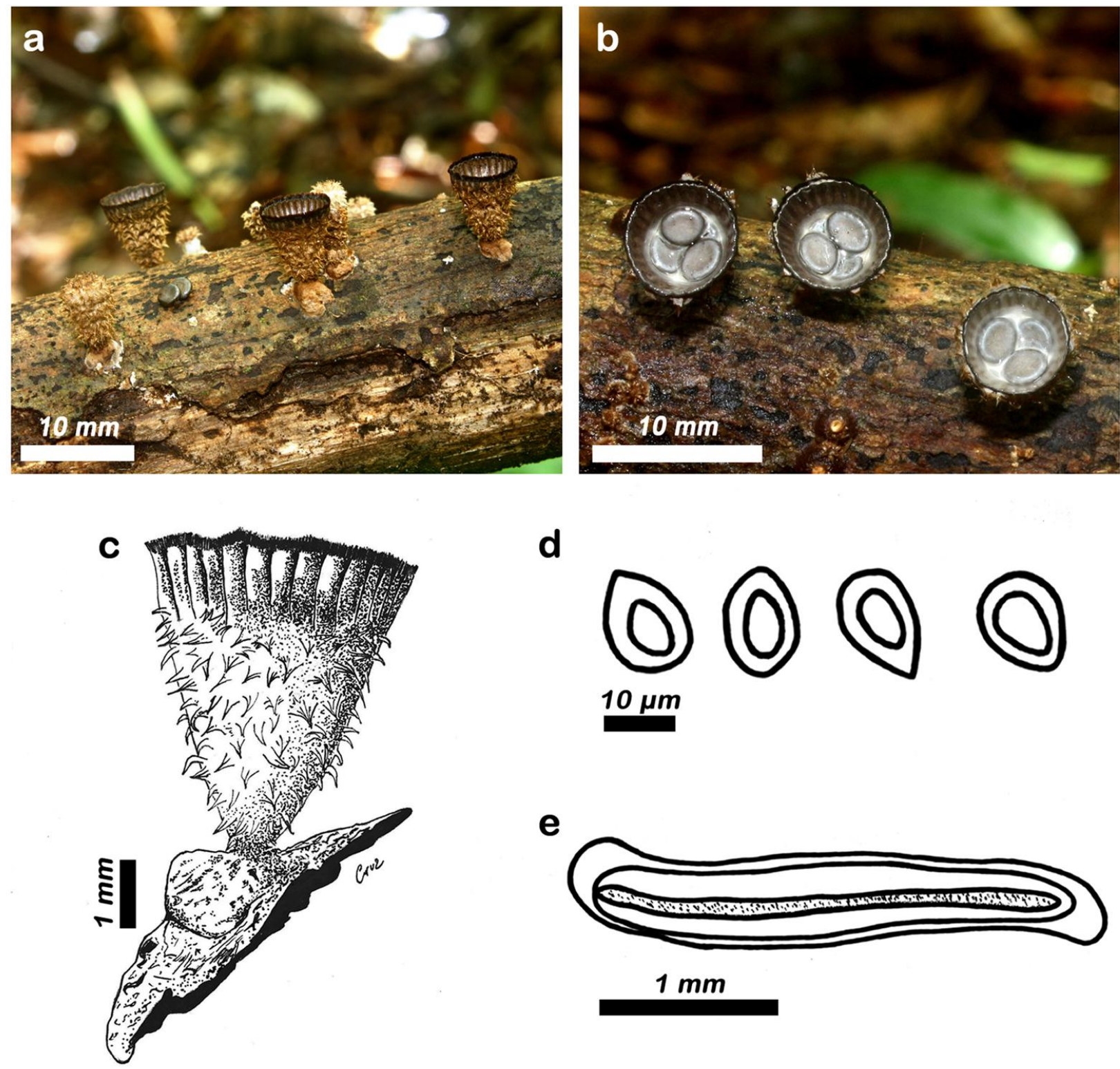

d

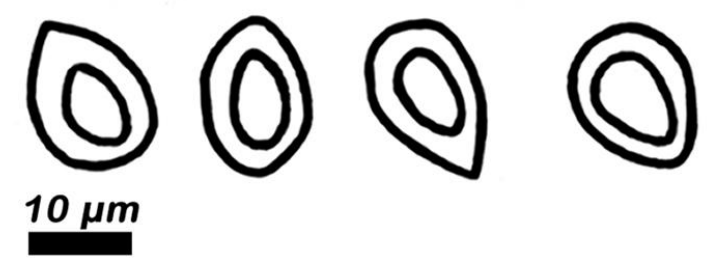

$\mathbf{e}$

Plate 1 - Cyathus morelensis. a, b Mature basidiomata. c Basidioma; d Droplet-like basidiospores; e Section of peridiole with double layer cortex.

the quotient of spore length (represented by "L") and width (represented by "W") and "n" is the number of spores observed.

\section{Results}

Cyathus morelensis C.L. Gómez \& PérezSilva, Mycotaxon 33: 419 (1988) Plate 1

Peridium infundibuliform, 7-10 $\mathrm{mm}$ high, 5-7 $\mathrm{mm}$ wide at the mouth, not expanding at the top or tapering abruptly at the base. Attached to the substrate by a conspicuous emplacement, $3.5-5 \mathrm{~mm}$ in diameter, brown (6E6, KW). Exoperidium with the same colouring as the emplacement, hirsute, plicate, with $0.5 \mathrm{~mm}$ between folds, covered with irregular and flexible tufts of hair; mouth minutely fimbriate, with $0.2 \mathrm{~mm}$ long, dark brown coloured tomentum $(8 \mathrm{~F} 4, \mathrm{KW})$. Endoperidium conspicuously plicate, with 0.5 $\mathrm{mm}$ between folds, yellowish brown (5D1, KW), slightly shiny. Epiphragm flexible, white; 12 peridioles per basidioma, greyish brown $(6 \mathrm{~F} 3, \mathrm{KW}), 2.8-3.2 \times 2-2.5 \mathrm{~mm}$, elliptical, angular to circular margin, with a double layer cortex and hyaline tunic. Basidiospores 14-19 × 9-13 $\mu \mathrm{m}(\mathrm{Qm}=1.51$; $\mathrm{L}=16.3 \mu \mathrm{m} ; \mathrm{W}=10.8 \mu \mathrm{m} ; \mathrm{n}=30$ ), smooth, hyaline, ovoid to elliptical, similar to droplets, thick-walled $(1-2.5 \mu \mathrm{m})$, apiculated in some spores. 
Known distribution - Mexico (Gómez \& Pérez-Silva 1988).

Material examined - Brazil, Amazonas, Manaus, Adolpho Ducke Reserve Forest, growing in groups on decaying wood, 22 Nov 2010, leg. R. Braga-Neto \& J.P.M. Araújo, INPA 239562.

\section{Discussion}

Originally described from Mexico (Gómez \& Pérez-Silva 1988), C. morelensis is considered close to $C$. limbatus Tul. \& C. Tul., however, the latter exhibits a more expanded upper basidioma in comparison with height; additionally, there are divergences in spore shape, which are normally elliptical to subglobous in most species of the genus. $C$. morelensis displays uniquely-shaped spores, which are ovoid with tapered extremities, resembling a droplet. According to traditional classification (Brodie 1975), C. morelensis belongs to the "poeppigii" group; but based on molecular studies (Zhao et al. 2007) is a member of the "striatum" group.

Greater investment in research expeditions to tropical areas of extreme biological importance is needed, focusing on species inventory using classic taxonomy and molecular tools, in order to widen knowledge of gasteroid fungi diversity in the Neotropics, where taxa as yet unknown to science are likely to be found. This is the second record of C. morelensis in the world and the first for South America.

\section{Acknowledgements}

The first and second authors would like to thank CAPES (Coordenação de Aperfeiçoamento de Pessoal de Nível Superior, Brazil) for providing the Master's scholarship and financial support. The authors also acknowledge Dr. Carlos Franciscón, Curator of
INPA Herbarium, for authorizing the loan of exsiccate.

\section{References}

Alfredo DS, Leite AG, Braga-Neto R, Baseia IG. 2012a - Two new Morganella species from the Brazilian Amazon rainforest. Mycosphere 3, 66-71.

Alfredo DS, Leite AG, Braga-Neto R, Cortez VG, Baseia IG. 2012b - Scleroderma minutisporum, a new earthball from the Amazon rainforest. Mycosphere 3, 294298.

Baseia IG, Milanez AI. 2001 - Cyathus (Gasteromycetes) in areas of the Brazilian Cerrado region, São Paulo State. Mycotaxon 80, 493-502.

Brodie HJ. 1975 - The Bird's Nest Fungi. Canada. University of Toronto Press.

Cruz RHSF, Barbosa MMB, Baseia IG. 2012 Cyathus badius and C. earlei reported from Brazilian Atlantic rainforest. Mycotaxon (submitted).

Gómez CL, Pérez-Silva E. 1988 - A new species of Cyathus from Mexico. Mycotaxon 33, 419-421.

Kornerup A., Wanscher JH. 1978 - Methuen Handbook of Colour. $3^{\text {rd }}$ Edition. Eyre Methuen (revised by Don Pavey). London.

Zhao RL, Jeewon R, Desjardin DE, Soytong K, Hyde KD. 2007 - Ribosomal DNA phylogenies of Cyathus: Is the current infrageneric classification appropriate? Mycologia 99, 385-395.

Zhao RL, Desjardin DE, Soytong K, Hyde KD. 2008 - A new species of bird's nest fungi: characterization of Cyathus subglobisporus sp. nov. based on morphological and molecular data. Persoonia 21, 71-76. 